\title{
Death Penalty: An Unethical Punishment
}

\author{
Hantao $\mathrm{Hu}$ \\ 3265 Wicklow lane, Gastonia, NC, 28056, USA. \\ 674540350@qq.com
}

Abstract: Starting from the early 19th century, the arguments on whether abolishing death penalty never reach an agreement and continue to today. This research paper focuses on discussing the reasons why society should abandon the death penalty. Based on the research and the analysis, the article mainly uses the utilitarian ethical values to argue that the death penalty is unethical:

1. Death penalty fails to deter the criminals.

2. The death penalty may brutalize the victim's family.

3. The death penalty is a more expensive means to achieve the same goal that life imprisonment can accomplish.

Therefore, the paper suggests the abolishment of the death penalty and recommends using life imprisonment as an alternative. In the future, the article will combine more resources and targets the death penalty from Kant's perspective and Aristotle's virtue ethics.

Keywords: Philosophy, Death Penalty, Utilitarianism, Life imprisonment, unethical punishment.

In 1767, Cesare Beccaria challenged the idea of death penalty in his essay, On Crimes and Punishment, which influenced the whole world, including the American intellectuals. As a result, the abolitionist movement of capital punishment took place in America in the early nineteenth century. ${ }^{1}$ The death penalty was abolished in many states, including Missouri and Pennsylvania. Still the argument over the death penalty never ceases. On one side, supporting the death penalty, people argue that the punishment should be legal due to its several positive impacts: (1) it deters criminal behavior; (2) it ends the criminals'lives, so they cannot do any further harm; (3) it costs much less than life imprisonment since the government must pay for the upkeep of these vicious criminals; (4) the death of the murderer provides a sense of justice and closure for the victims' family.

As a person who lives in China, a nation that has the death penalty for some extreme crimes, I think the government should abolish such capital punishment because it is not the best means to pursue the most just end. In the framework of Utilitarianism, the measure for right action is pursuing the greatest good for the greatest number, and even killing is allowed if necessary for that end. But Utilitarianism also argues that an action is only ethical if there is no better solution to pursue the greatest good for the greatest number. In the case of death penalty, however, although it might seem to meet the first requirement, it fails to meet the second, because life imprisonment can produce a greater good for more people, since it accomplishes all the death penalty offers without killing a person and spending much unnecessary money.

Many people in favor of the penalty people argue that it has long been used as an efficient way to keep the society in order through deterring people from crimes and bringing criminals to justice. It sounds ethical to

1. "Introduction to the Death Penalty," DPIC, https://deathpenaltyinfo.org/part-i-history-death-penalty\#abol. 


\section{Death Penalty: An Unethical Punishment}

sacrifice an unjust person for the peace of the whole society. However, this argument has a faulty premise that the death penalty deters crime. Due to commonsense reasoning, humans like to draw a conclusion from history and connect such a conclusion with a cause or a reason, but such assumptions must be supported by evidence. From the study of historical records, we learn that many people were executed for threatening the reign of a king. Executions thereby served as threats to his citizens to prevent them from crimes. Moreover, ancient executions usually took place in the public, imposing fear on the onlookers; while modern executions are censored out of the sight of the society. These citizens were not scared by nature or ethics but by the tyrants who controlled their lives. From this point, we can see the distinct difference between the death penalty nowadays and the past. Therefore, to decide whether death penalty is ethical or not, we must use the information in modern society.

Data collected from the Death Penalty Information Center contradicts the premise of the deterrence of crime. In the past ten years, the average murder rate per 100,000 people in states with the death penalty is higher than the murder rate in states without death penalty in the same decade. For example, in 2008, the murder rate in states with death penalty was 5.2, while the murder rate in states without death penalty was 3.3.In addition, in 2016, the murder rate in states with death penalty was 5.4, but the murder rate in states without death penalty was 3.9. From the data, we can see that in states with the death penalty, the murder rate has not decreased at all; on the contrary, it has slightly increased. Moreover, the average murder rates of most states decreased after the abolishment of the death penalty. For instance, in Illinois, the rate decreased from 7.11(the average murder rate from 1996 to the abolishment of the death penalty) to 6.17(the average murder rate from the abolishment to 2016). Similarly, in Connecticut, the rate decreased from 3.29 to 2.86 after that state abolished the death penalty. ${ }^{2}$ Besides, according to FBI Uniform Crime Report in 2016, consistent with previous years, the south had the highest homicide rate event, even though it accounted for $80 \%$ of executions, which reveals the death penalty fails to deter the criminals in south. ${ }^{3}$ All this evidence points to a conclusion that the death penalty has no correlation to a reduction in murder rates.Another argument in favor of the death penalty is that the death penalty ends the criminal's life and future, making society safer with fewer threats. I do agree that a society with fewer threats is safer to live in, and the death penalty achieves the goal: bringing the unjust to justice and stops the spreading of violence is a social good. However, the death penalty is not the only means to reach this end. Life imprisonment does the job just as well.

Comparing the death penalty and the life imprisonment, the former is a more expensive means than the latter. First, the death penalty directly results in the death of the criminal. No matter which methods are used to kill the criminal, this kill is intentional and deliberately planned. Putting aside the ethics of such an act for the purposes of this argument, we can at least agree that the state of removing a person's life, except for its positive effects on the rest of the society, is not ideal, the legality of the action notwithstanding. Life imprisonment, on the other hand, merely imprisons the criminals to stop their further damage to the society, averting the unnecessary killing. Now, some people may argue that life imprisonment leads the state to take away a person's rights in every other respect, which is also dangerous. Personally, I agree with the viewpoint, but still, when comparing the removal of one's liberty to the removal of one's life, liberty is not as high a price.

2. "Murder Rates Nationally and By State," DPIC, https://deathpenaltyinfo.org/murder-rates-nationally-and state\#MRord.

3. "Facts about the Death Penalty," DPIC, https://deathpenaltyinfo.org/documents/FactSheet.pdf, (September 17, 2018). 


\section{Death Penalty: An Unethical Punishment}

Second, the monetary cost of death penalty is extremely high. For a single death penalty trial, the state needs to pay more than one million dollars more than for a non-death penalty trial; of all the death penalty cases that go to trial, only one-third of them results in a death penalty sentence, and only one-tenth of them actually results in an execution. If we add up these fees and do the simple calculation, 1 (the extra 1 million dollars paid to the trial) $x 3(1 / 3$ that results in death penalty) $\times 10(1 / 10$ results in execution $)=30$, we can easily figure out the real cost behind each death penalty execution is approximately 30 million dollars, which comes from the taxation we pay. ${ }^{4}$ Life imprisonment, on the other hand, costs around ninety thousand dollars annually. ${ }^{5}$ If the money saved from death penalty trials is spent on security and the police, wouldn't it help keep society safer? Or, if we distribute the money to hire more psychologists and better teachers to help treat these criminals, helping people with criminal tendencies in their childhood and guiding them to the ethical path, wouldn't that be a better approach than trying to fix the harm they caused? Both outcomes are preferable, and therefore life imprisonment has the greater utility.

The death penalty also has the risk of killing an innocent person if the judgement is unjust. Killing someone is already a great presumption; to murder an innocent person is even more reprehensible. Now, the counterargument may be this: the judgement goes through multiple courts, is supported by manifold evidence, and most people achieve consistency in their verdict, so it cannot be wrong under such a strict process. But such cases do exist. For example, Mr. Nie, a man who was accused of raping and killing Ms. Kang, was sentenced to death and executed in April,1995 in Hebei, China. In 2005, Mr. Wang confessed to murdering Ms. Kang. After 11 years of campaigning, Mr. Nie's family finally persuaded the Supreme Court exonerate Mr. Nie. ${ }^{6}$ But this outcome cannot bring Mr. Nie back to life. But if a person is imprisoned for life due to some mistake, he could be released once the truth emerges.

Finally, some may argue the death of the criminal can greatly console the victims' families. Without doubt, the just punishment comforts the victims and victims' families a great deal, but the death penalty may also brutalize these innocent people, making them feel a greater desire for hatred and revenge. Not only does the imprisoning the criminal prevent such brutalization, but it also offers the prisoners a chance to realize their wrongdoing, thereby saving themselves mentally. Although some criminals won't regret their wrongs, others will still want to grasp the last hope and compensate for their guilt. If they get parole from the governors or the president by chance, they could help prevent people from crime by addressing the public on their unique experiences and the lessons they learned. Also, they could sincerely apologize to the victim's family and make up for their loss, which is a greater consolation than their brutal death.

In conclusion, abolishing the death penalty is ethical and right. Even though the government would have to hire more security officers to guard the criminals, this small sacrifice produces a huge amount of benefit to the society in whole. The government can save a huge amount of unnecessary cost, prevent the victims' families from becoming brutalized, and still prevent the criminals from harming society. The good consequence and the wide influence of the abolishment outweigh its cost; thus, it is ethical, and we should abolish the death penalty.

4. Richard C. Dieter, "Smart on Crime: Reconsidering the Death Penalty in a Time of Economic Crisis," https:// deathpenaltyinfo.org/documents/CostsRptFinal.pdf, (October, 2009).

5. "Cost of the Death Penalty," DPIC, https://deathpenaltyinfo.org/costs-death-penalty.

6. Michael Forsythe, "China Exonerates Man It Executed for Murder in 1995," https://www.nytimes. com/2016/12/02/world/asia/china-court-exonerates-innocent-executed.html, (December 2, 2016). 


\section{REFERENCES}

Forsythe, Michael. “China Exonerates Man It Executed for Murder in 1995." The New York Times, 2 Dec. 2016, https://www.nytimes.com/2016/12/02/world/asia/china-court-exonerates-innocent-executed.html. Accessed by 19 Sep. 2018.

“The Abolitionist Movement.” DPIC, https://deathpenaltyinfo.org/part-i-history-death-penalty\#abol.

“Murder Rates Nationally and By States.” DPIC, https://deathpenaltyinfo.org/murder-rates-nationally-andstate\#MRord.

"Facts About the Death Penalty," DPIC, 17 Sep. 2018, https://deathpenaltyinfo.org/documents/FactSheet.pdf.

Dieter, Richard C. "Smart on Crime: Reconsidering the Death Penalty in a Time of Economic Crisis." DPIC, https:// deathpenaltyinfo.org/documents/CostsRptFinal.pdf. Accessed 19 Sep. 2018.

Citation: Hantao Hu. "Death Penalty: An Unethical Punishment". American Research Journal of Humanities and Social Sciences, vol 4, no. 1, 2018, pp. 1-4.

Copyright (C) 2018 Hantao Hu. This is an open access article distributed under the Creative Commons Attribution License, which permits unrestricted use, distribution, and reproduction in any medium, provided the original work is properly cited. 